\title{
マルチトールの代謝について
}

\section{Clinical Experiment on Maltitol Metabolism}

岡山大学医学部第 2 内科 (Department of Medicine, Okayama University Medical School)

$\begin{array}{llllll}\text { 鴨 井 正 樹 (Masaki Kamoi) } & \text { 清 } & \text { 水 } \text { 能 人 (Yoshito Shimizu) } \\ \text { 河 内 光 男 (Mitsuo Kawauchi) } & \text { 藤 } & \text { 井 } \text { 靖 久 (Yasuhisa Fujii) } \\ \text { 菊 池 武 久 (Takehisa Kikuchi) } & \text { 水 } \text { 川 土 郎 (Shiro Mizukawa) } \\ \text { 吉 岡 溥 夫 (Hiroo Yoshioka) } & \text { 木 畑 正 義 (Masayoshi Kibata) }\end{array}$

林原生物化学研究所 (Hayashibara Biochemical Laboratories, Inc.)

三 橋 正 和 (Masakazu Mitsuhashi)

The metabolism of orally administered maltitol was investigated and compared with clinical study, especially in two groups, one which exhibited diabetic type and the other non-diabetic type (contained intermediate type) in $50 \mathrm{~g}$ glucose tolerance test.

The following results were obtained. The variation curves of blood sugar, immunoreactive insulin, and non-esterified fatty acids levels effected by $50 \mathrm{~g}$ maltitol tolerance test in both groups had been extremely lower than those effected by $50 \mathrm{~g}$ glucose tolerance test.

So, it was considered that maltitol per se had been hardly absorbable through intestinal wall, clinically as so with animal study. In the case of concurrent administration of $50 \mathrm{~g}$ maltitol and $50 \mathrm{~g}$ glucose, the absorption of glucose was inhibited, resulting in a lower increase of blood sugar level than in the case of an individual administration of $50 \mathrm{~g}$ glucose.

\section{緒言}

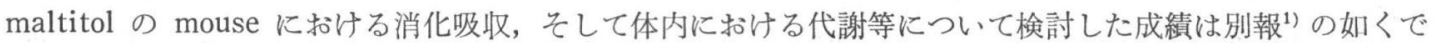
める。Dahlqvistら ${ }^{2)}$ の報告も著者等とほほ济同様であって，本剤が経口摂取されても腸内での分解及び吸収は 極めて僅かであり，従って吸収されて熱源となる可能性も極めて少ないものであると考劣られる。本剤が臨床 的に使用された場合の動態についての検討は尚不充分であると思われるので，著者らは林原生物化学研究所よ り提供された本剤（市販名マービー）について以下の如き種々の面から，特に糖代謝異常を中心に検討を行な ったのでその成績について述べる。

\section{実 験 の 部}

実験 I $50 \mathrm{~g}$ glucose 及び $50 \mathrm{~g}$ maltitol 負荷テスト

1 被験対象

岡山大学附属病院入院患者及び関係病院入院患者であり, コントロール群として $22 \sim 73$ 才迄(平均年令 48 才) の32人（令23人, ㅇ 9 人) を選んだ。勿論これらはたと光何等かの疾患を有しているにしても, 日本糖尿病学 会診断基準委員会の基準3)にて正常又は境界型を示すもので，糖尿病型を示すものは全く含んでいない。又， 糖尿病者群としては, 上記基準にて糖尿病型を示した 43 〜3才（平均年令 63 才）迄の 15 人（令 9 人, 우 6 人) を選んだ。 


\section{2 実験方法}

同一被験者につき日を变えて早朝空腹時に $50 \mathrm{~g}$ glucose 及び $50 \mathrm{~g}$ maltitol をそれぞれ $300 \mathrm{~m} l$ の水溶液 として経口投与した。そして投与前, 投与後 30 分, 60 分, 90 分, 120 分及び 180 分に夫々採血して試験に供し た。即ち, 成長ホルモン (以下 HGH と略す) 測定には heparin を加え, 血糖, immunoreactive insulin (以 下 IRI と略す) 及び遊離脂肪酸（以下 NEFA と略す）測定には heparin を加えずに肘静脈より採血した。

\section{3 検査方法}

血糖はオートアナライザー法4)，IRI はダイナボットキットを使用した二抗体法5)6)，NEFAはItaya·Ui 法7)， HGH はダイナボットキットを使用した二抗体法帛を用いた。

\section{4 実験成績}

1）血糖曲線について

図 1 に示す如くコントロールにとった非糖尿病者群に批いて, $50 \mathrm{~g}$ glucose 負荷試験（以下 $50 \mathrm{~g}$ GTT と略す）は黒丸実線で 示した様に負荷前 $93 \pm 12$, 負荷後 30 分 $147 \pm 24,60$ 分 $133 \pm 29$, 90 分 $121 \pm 30,120$ 分 $104 \pm 25,150$ 分 $87 \pm 16,180$ 分 $79 \pm 16 \mathrm{mg} / \mathrm{d} l$ であったのに対して，50 g maltitol負荷試験（以下 $50 \mathrm{~g}$ MTTと 略す）は白丸実線で示した様に負荷前 $93 \pm 13$, 負荷後 30 分109土 $24 ， 60$ 分 $105 \pm 19 ， 90$ 分 $97 \pm 15 ， 120$ 分 $95 \pm 14 ， 150$ 分 $94 \pm 15,180$ 分 $90 \pm 14 \mathrm{mg} / \mathrm{d} l$ と 30 分後, 60 分後に僅か上界を示したのみでほほ 平坦な曲線を描いた。 $50 \mathrm{~g}$ GTT 時, $50 \mathrm{~g}$ MTT 時共に最高血糖伯 を示した時間は負荷後 30 分であった。つぎに糖尿病者群につい てみると $50 \mathrm{~g}$ GTT は黒丸点線の如之, 負荷前 $139 \pm 50$, 負 荷後 30 分 $210 \pm 49,60$ 分 $242 \pm 64,90$ 分 $250 \pm 71,120$ 分 232 $\pm 71,150$ 分 $203 \pm 85,180$ 分 $186 \pm 87 \mathrm{mg} / \mathrm{d} l$ であったが, $50 \mathrm{~g}$ MTT は白丸点線の如く, 負荷前 $130 \pm 40$, 負荷後 30 分 $152 \pm$ $34 ， 60$ 分 $161 \pm 39 ， 90$ 分 $161 \pm 47 ， 120$ 分 $156 \pm 51 ， 150$ 分 148 $\pm 53,180$ 分 $141 \pm 50 \mathrm{mg} / \mathrm{d} l$ であり血糖の変動は僅かであった。

Blood Sugar

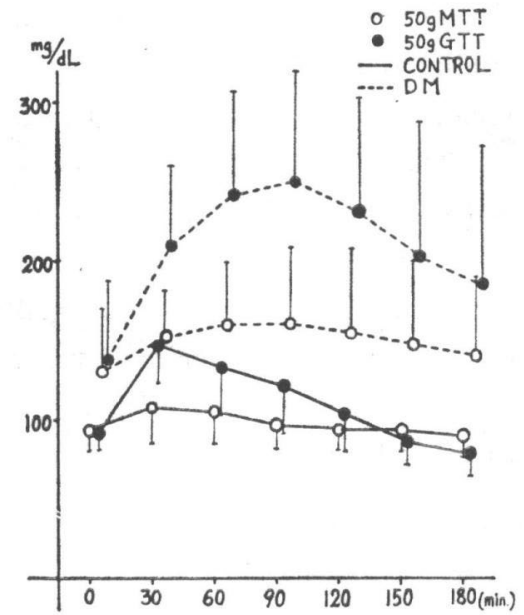

図 1 Comparison of $50 \mathrm{~g} \mathrm{mal}$. titol tolerance test (MT $\mathrm{T})$ with $50 \mathrm{~g}$ glucose tolerance test (GTT) in co. ntrol and DM

又, $50 \mathrm{~g}$ GTT, $50 \mathrm{~g}$ MTT 時共に負荷後 90 分に最高血糖値を示した。負荷後 30 分間での血糖の上昇を $\triangle$ で示し両負荷間での比を求めると, $\triangle \mathrm{GTT} / \triangle \mathrm{MTT}$ はコントロール群では 3.4 , 糖尿病者群では 3.8 であっ た。

2) IRI 曲線について

図 2 に示す如く実線で示したコントロール群についてみると, $50 \mathrm{~g}$ GTT 時の IRI 值の変動は負荷前 11 \pm 7 , 負荷後 30 分 $76 \pm 49,60$ 分 $80 \pm 59,90$ 分 $65 \pm 57,120$ 分 $43 \pm 39,150$ 分 $24 \pm 28,180$ 分 $15 \pm 11 \mu \mathrm{U} / \mathrm{ml}$ であったが，50g MTT 時における IRI 值は負荷前 $11 \pm 6$, 負荷後 30 分 $26 \pm 15 ， 60$ 分 $23 \pm 14,90$ 分 $19 \pm$ 11，120分 $16 \pm 9,150$ 分 $14 \pm 10,180$ 分 $13 \pm 8 \mu \mathrm{U} / \mathrm{ml}$ とほほ平坦な曲線を描いた。最高 IRI 值を示す時間 は何れを負荷した場合も30〜60分後であった。これに対して糖尿病者群においては点線の如く $50 \mathrm{~g}$ GTT 時 の IRI 值は負荷前 $13 \pm 11$, 負荷後 30 分 $35 \pm 23 ， 60$ 分 $33 \pm 25 ， 90$ 分 $43 \pm 34 ， 120$ 分 $40 \pm 33,150$ 分 $24 \pm 21$, 180 分 $25 \pm 23 \mu \mathrm{U} / \mathrm{m} l$ であり, 点線で示す如く $50 \mathrm{~g}$ MTT 時の IRI 值は負荷前 $19 \pm 9$, 負荷後 30 分 $25 \pm 15$, 
IRI

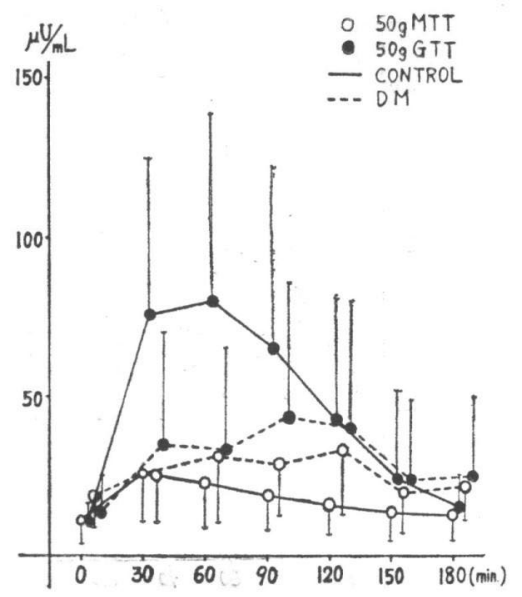

図 2 Comparison of $50 \mathrm{~g}$ MTT with $50 \mathrm{~g}$ GTT in control and DM
NEFA

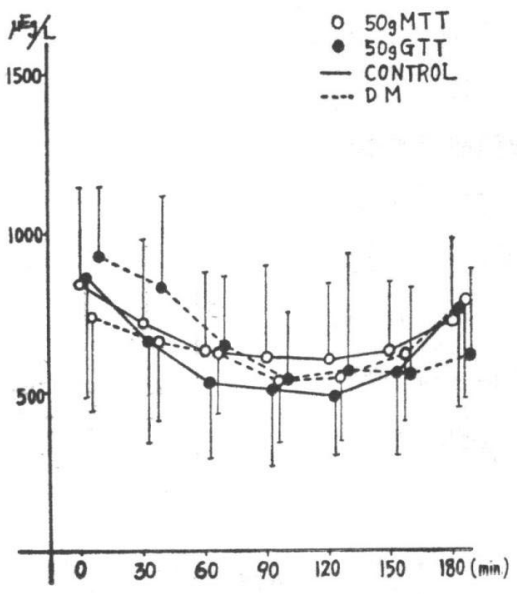

図 3 Comparison of $50 \mathrm{~g}$ MTT with $50 \mathrm{~g}$ GTT in control and DM

60分 $31 \pm 19,90$ 分 $29 \pm 16,120$ 分 $33 \pm 20,150$ 分 $20 \pm 13 ， 180$ 分 $22 \pm 11 \mu \mathrm{U} / \mathrm{m} l$ と変動が少なかった。最高 IRI 值を示す時間は何れを負荷した場合も值荷後90〜120分であった。負荷後30分間での IRI 値の上昇を両負 荷間で比較すると, $\triangle \mathrm{GTT} / \triangle \mathrm{MTT}$ はコントロール群で 4.7 , 桾尿病者群で 3.0 であった。

3） NEFA 曲線について

図 3 に示す如く実線で示したコントロール群についてみると，50 g GTT 時の NEFA 值の変動は負荷前

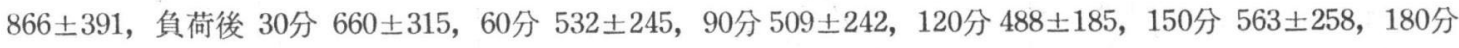
$774 \pm 316 \mu \mathrm{Eq} / l$ であった。これと対して $50 \mathrm{~g}$ MTT 時に括ける NEFA 值は負荷前 $839 \pm 303$, 負荷後 30 分 $720 \pm 267,60$ 分 $630 \pm 259,90$ 分 $614 \pm 287,120$ 分 $607 \pm 240,150$ 分 $630 \pm 229,180$ 分 $724 \pm 258 \mu \mathrm{Eq} / l$ と平坦 な曲線を描いた。点線で示した糖尿病者群についてみると，50 g GTT 時の NEFA 值は負荷前 $936 \pm 222$, 負荷後 30分 $829 \pm 292 ， 60$ 分 $647 \pm 224 ， 90$ 分 $534 \pm 213 ， 120$ 分 $567 \pm 363 ， 150$ 分 $553 \pm 289 ， 180$ 分 $620 \pm 277$ $\mu \mathrm{Eq} / l$ であった。これに対して $50 \mathrm{~g}$ MTT 時の NEFA值は負荷前 $738 \pm 302$, 負荷後 30 分 $664 \pm 256$, 60分 $622 \pm 198,90$ 分 $530 \pm 195 ， 120$ 分 $546 \pm 211 ， 150$ 分 $625 \pm 219 ， 180$ 分 $790 \pm 308 \mu \mathrm{Eq} / l$ と平坦な曲線を描いた。 負荷後 30 分間での NEFA 值の低下を両負荷間で比較すると, $\triangle \mathrm{GTT} / \triangle \mathrm{MTT}$ はコントロール群，糖尿病 者群とも 1.8 であった。

4) HGH 曲線について

HGH とついては図 4 に示す如く一定の傾向を見い出せなかった。

実験 II (50 g glucose+50 g maltitol) 負倏テスト

つぎに maltitol が glucose の吸収に及ぼす影響をみるためにつぎの被験対象に maltitol と glucose を 同時に負荷して検討した。

\section{1 被験対象}

即ち23〜 70 才迄の 5 人 (平均年令 50 才, 今 2 人, 우 3 人) である。

\section{2 実験方法}

$50 \mathrm{~g}$ glucose 及び $50 \mathrm{~g}$ maltitol に水を加え $300 \mathrm{~m} l$ とし, これを経口投与して上記と同様の方法で実験を 行なった。 
3 検查方法

上記と同様である。

4 実験成績

1）血糖曲線について

5 例の平均値について みると図 5 に三角で示す 如く負荷前 $95 \pm 16$, 負荷 後 30 分 $143 \pm 45$, 負荷後 60 分 $140 \pm 43,90$ 分 152 $\pm 50 ， 120$ 分 $124 \pm 28 ，$

150 分 $121 \pm 21,180$ 分 $112 \pm 18 \mathrm{mg} / \mathrm{d} l$ と最高血 糖值を示す時間が負荷後 90分となり, $50 \mathrm{~g} \mathrm{GTT}$ 時, $50 \mathrm{~g}$ MTT 時の 60 分後に比べ遅趧した。 又, 負荷後 30 分, 60 分, 90 分で 50 g GTT 時, $50 \mathrm{~g}$ MTT 時のほぼ中間 值を示した。

2) IRI 曲線について 四 6 に示与如く負荷前 $12 \pm 4$, 負荷後 30 分 $71 \pm$ $55 \mu \mathrm{U} / \mathrm{ml}$ と上㫒, 60 分 72 $\pm 30,90$ 分 $78 \pm 44,120$ 分 $73 \pm 52,150$ 分 $53 \pm 21,180$ 分 $45 \pm 24 \mu \mathrm{U} / \mathrm{ml}$ で, 最 高值は $50 \mathrm{~g}$ MTT 時の 負荷後 60 分より遅延し $50 \mathrm{~g} \mathrm{GTT}$ 時の負荷後90分より遅延傾向を 示した。負荷後60分, 90 分は $50 \mathrm{gGTT}$ 時, $50 \mathrm{~g}$ MTT時のほぼ 中間值を示した。

3) NEFA 曲線について

図7 に示与如く負荷前 $1069 \pm 474$, 負荷後 30 分 $564 \pm 92,60$ 分 $494 \pm 89,90$ 分 506士288，120分 431士121，150分 569土236，180分 $535 \pm 280 \mu \mathrm{Eq} / l$ と負荷後 30 分で $50 \mathrm{~g}$ GTT 時, $50 \mathrm{~g}$ MTT 時の NEFA 值より下降が早く大きかったが，以後は徐々に下降し150分 後で僅か上昇した。
Blood Sugar

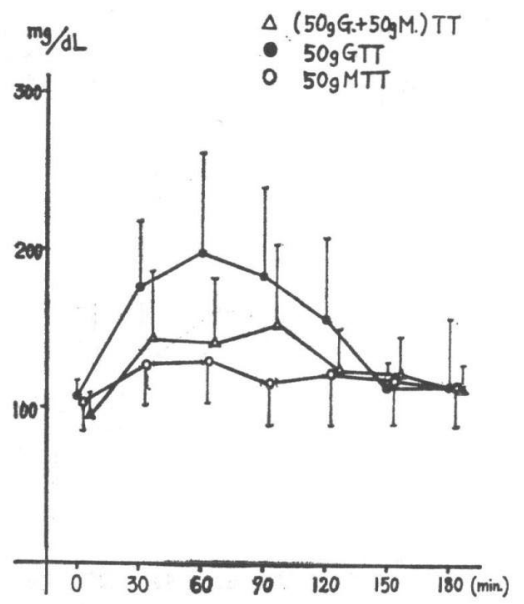

汹 5 (50 g G+50g M) TT

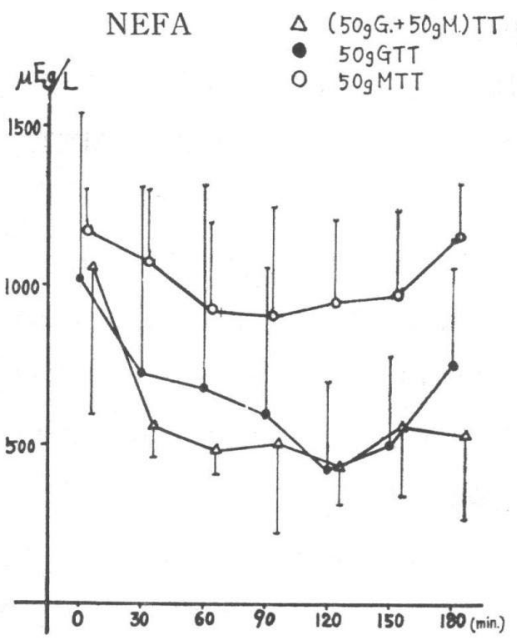

図 $7 \quad(50 \mathrm{~g} \cdot \mathrm{G}+50 \mathrm{~g}$ M) TT

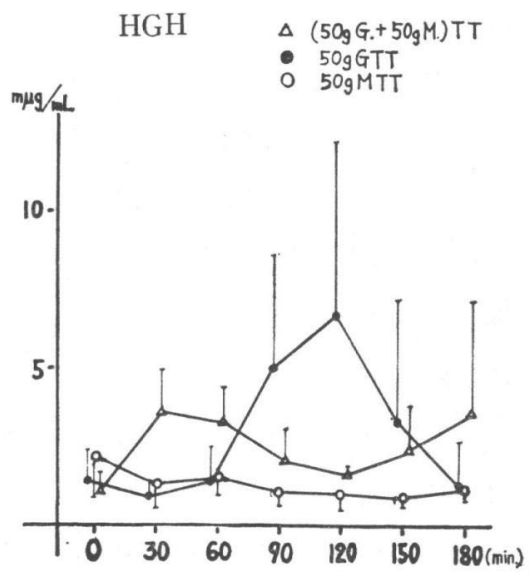

図 8 (50 g G+50.g M) TT 
4) HGH 曲線について

図 8 に示す如く負荷前 $1.1 \pm 0.6 \mathrm{~m} \mu \mathrm{g} / \mathrm{ml}$, 負荷後 30 分 $3.6 \pm 1.4 \mathrm{~m} \mu \mathrm{g} / \mathrm{m} l$ と上年, 60 分 $3.3 \pm 1.2,90$ 分 $2.0 \pm 1.1,120$ 分 $1.6 \pm 0.2 \mathrm{~m} \mu \mathrm{g} / \mathrm{m} l$ と下降し, 150 分 $2.4 \pm 1.4,180$ 分 $3.6 \pm 3.6 \mathrm{~m} \mu \mathrm{g} / \mathrm{m} l$ と再び上升した。

\section{考案}

maltose に水素添加することにより新たに maltitol が生成される。このものは maltase その他の酵素の影 響を殆ど受けないので単糖への分解は殆ど認められない。しかも，甘味の点では蔗糖と同程度の甘味度を有し ている゚゙。このものが生体に経口投与された場合の動態は, 生体の腸管内でも単糖類への分解が殆ど行なわれ ないといら成績から極めて興味深い。分解されない場合には吸収飞抑制されることになり ${ }^{10)}$, 従ってエネルギ 一源として生体に取り入れる度合が少ないとみなされる。このことは臨床的な立場でみた時, 肥满者, 糖尿病 者にとって甘味を与光るがカロリ一は与光ないといら利点から極めて有利な食品たり得る。そこで私共はこの 点をより明らかにする目的で glucose と比較しながらその分解吸収について, 特に $50 \mathrm{~g}$ glucose 負荷により 糖代謝の異常を示すものに括いて,いかなる動態を示すかという点についての検討を行なった。実験成績で明 らかな様に $50 \mathrm{~g}$ maltitol 負荷を行ない血糖の変動をみると, コントロール群, 糖尿病者群ともに僅かの上昇 しか示さなかった。既報 ${ }^{1)} の$ 如く, mouse に ${ }^{14} \mathrm{C}$-maltitol (U) を経口投与し経時的に眼窩静脈より採血した ものについて paperchromatography の radioautography により追究した成績では血中にある放射性の物質 は微量の glucose か sorbitol であり, maltitol は殆ど検出し得ない程度でめった。即ち, mouse の実験か らは maltitol 慬かしか吸収されないことを確めている。これより扰そらく僅かの血糖上䒜は maltitolでな くとの分解物であるうと考光られる。IRI 值もコントロール群, 糖尿病者群に执いて maltitol 負荷では变動 が少ないことが知られた。これは血糖の変動が少ないので, ブドウ糖によるインシュリン分泌刺激も少ないた めであろらと考觉られる。NEFA の変動についても血糖值に相関している様に思われる。そして maltitol 負 荷にて血桾值の変動の少ない場合はコントロール群, 糖尿病者群ともとの動きは少ないことがみられた。即 ち，NEFA は笳肉組織で利用されたり，肝蔵や脂肪組織で再びエステル化されて中性脂肪になる。この時，血 液中のブドウ糖が脂肋組織に取り込まれると活性のグリセロールができ, これがNEFAとエステル結合して中 性脂肪になるので女る。従って，血糖が上升すればその利用に際してNEFAが必要となり，血中の NEFA は低

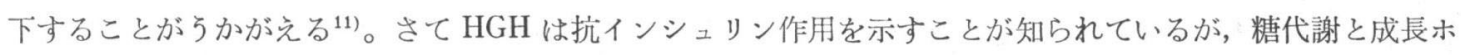
ルモンの関係について多くの報告 ${ }^{12)}{ }^{14)}$ がある。Yalowら ${ }^{15)}$ によれば正常人に $100 \mathrm{~g}$ ブドウ糖を経口的に投与 すると 1 〜 時間は血中 $\mathrm{HGH}$ は低下するが， 3 時間頃から上年しはじめ，4～ 5 時間で頂值に達する。又， 糖尿病者では飢餓時, ブドウ糖投与時に HGH の反応は強まらない。空腹時の HGH は正常と糖尿病のいかな る型もコントロールの程度, 病期によっても変わらず酸血症でも正常であるが, インシュリン療法で夜間血糖 が下がると HGH は上㫒すると報告している。本実験ではコントロール群, 糖尿病者群とも maltitol 負荷では 特記すべき反応を示さないとみなされる成績である。

つぎに, maltitol をglucose と共に経口投与した場合, glucose の吸収動態が maltitol に影響されるか否 かは興味深いテーマである。そこで $50 \mathrm{~g}$ maltitol と $50 \mathrm{~g}$ glucose を同時に負荷してみたところ, 最高血糖 值を示す時間が $50 \mathrm{~g}$ GTT 時より遅延し, 又, 負荷後 30分, 60分, 90分で $50 \mathrm{~g}$ GTT 時, $50 \mathrm{~g}$ MTT 時 の中間値を示した。この理由として種々のことが考劣られるが，何れにしてもブドウ糖の腸内での吸収を maItitol が妨げていると考学られる結果である。IRI, NEFA についても血糖值に相関した变動を示した。この 
場合, 兩者の投与量の比率が問題になるし, 下峲等の発現との間にも関連が女ると思われるが, 甘味料として の取报いに興味ある示唆を与えるものと思 5。HGH は負荷後30分に上昇を示したが，正常範囲であり一定の 傾向を見い出せない。尚，副作用としては下峲のみられることで， $50 \mathrm{~g}$ maltitol 投与後下峲を招こしたもの はコントロール群 32 人中 20 人 (62.5\%), 糖尿病者群 15 人中 2 人 (13.3\%) であった。又, (50 g maltitol+ $50 \mathrm{~g}$ glucose) 投与後では 5 人中 3 人に下峲があった。これは maltitol が腸管より殆ど吸収されないためて あろう。 $50 \mathrm{~g}$ maltitol 投与時, 糖尿病者に下痢の少ない理由は不明であるが, これも興味ある課題である。

\section{結—語}

maltitol の経口投与時の代謝動態について, 臨床例, 特に糖代謝異常のある群とない群について比較検討し たところ, 何れの群に物いても50 g MTT 時の血糖, IRI, NEFA の変動が $50 \mathrm{~g}$ GTT 時に比し極めて少な かった。即ち，臨床例に招いても maltitol が殆ど吸收されないことを知り得た。又，50 g maltitol と $50 \mathrm{~g}$ glucose を同時に負荷すると，glucose 自体の吸収は何等かの機転により阻害され，血糖の上昇が $50 \mathrm{~g}$ glucose 単独負荷よりは低值を示した。

稿を終るにあたり，御指導御校閲を賜わりました恩師平木教授に感謝致します。

文献

1) 鴨井正樹 他：マルチトールの代謝 (基礎編), 医学のあゆみ 投稿中

2) Arne Dahlqvist and Ulf Telenius: The Utilization of a Presumably Low-Caryogenic Carbo. hydrate Derivative, Acta Physiol. Scand., 63, 156-163 (1965)

3 ）葛谷信貞 他：糖負荷試験に批ける糖尿病, 診断基準委員会報告, 糖尿病, 13 (1), 1-7 (1970)

4) 柴田 進, 丹羽正治 他編：臨床化学分析III, p. 21-23, 東京化学同人, 東京 (1969)

5) Morgan, R.C. and Lazarow, A.: Immunoassay of Insulin, Two Antibody System, Diabetes, 12, 151 (1963)

6) Hales, C.H. and Randle, P. J.: Immunoassay of Insulin with Insulin-Antibody Precipitate, Biochem. J., 88, 137 (1963)

7) Itaya, K. and Ui, M.: Colorimetric determination of free fatty acids in biological fluids, $J$. Lipid Research, 6, 16 (1965)

8) W. M. Hunter and F.C. Greenwood: Preparation of Iodine-131 Labelled Human Growth Hormone of High Specific Activity, Nature, 194, 495 (1962)

9 ）小田恒郎：マルビットの食品工業への利用, 食品工業, 14 (3下), 44-47 (1971)

10）奥 恒行 他：白ネズミに抢けるマルチトールーU- ${ }^{14} \mathrm{C}$ の吸収と排泄, 栄養と食糧, 24(7), 399-404(1971)

11) Randle, P. J. et al. : The glucose fatty-acid cycle, its role in insulin sensitivity and the metabolic disturbances of diabetes mellitus. Laneet, 785 (1963)

12) Hunter, W. M., et al.: Plasma Growth Hormone after an Overnight Fast and following Glucose Loading in Healthy and Diabetic Subjects, Metabolism., 15 (7), 596-607 (1966)

13）入汇 実：成長ホルモン分泌の代謝性調節，日本内分泌学会雑誌，44，977-986 (1968)

14) Roth, J., et al.: Hypoglycemia: A Potent Stimulus to Secretion of Growth Hormone. Sci. ence, 140, 987-988 (1963)

15) Yalow, R. S., et al.: Plasma Insulin and Growth Hormone Levels in Obesity and Diabetes, Annals New York Academy of Sciences, 131, 357-373 (1965) 